\title{
Nutritional value and economic feasibility of red beetroot (Beta vulgaris L. ssp. vulgaris Rote Kugel) from different production systems
}

\author{
Sasa Straus ${ }^{1,2^{\star}}$, Franc Bavec ${ }^{2}$, Matjaz Turinek ${ }^{2}$, Ana Slatnar ${ }^{3}$, Crtomir Rozman $^{4}$ and \\ Martina Bavec ${ }^{2}$ \\ ${ }^{1}$ Panvita d.d. Lendavska 5, Rakičan, 9000 Murska Sobota, Slovenia. \\ ${ }^{2}$ Faculty of Agriculture and Life Sciences, Institute for Organic Farming, University of Maribor, Hoce, Slovenia. \\ ${ }^{3}$ Department of Agronomy, Biotechnical Faculty, Chair for Fruit, Wine and Vegetable Growth, University of Ljubljana, \\ Ljubljana, Slovenia. \\ ${ }^{4}$ Department of Agricultural Economics, Faculty of Agriculture and Life Sciences, University of Maribor, Hoce, Slovenia. \\ Accepted 29 September, 2012 \\ The study determined the internal quality (the total phenol, sugar, organic acid contents, antioxidant \\ activity, and mineral components) and physical parameters in the flesh of red beetroots produced in \\ different production systems (conventional, integrated, organic, and control) using established \\ methods. Organic cropping of red beetroot plants significantly reduced the yield by $27 \%$ of some macro \\ minerals ( $\mathrm{P}$ at 23.1, $\mathrm{K}$ at 13.1, and $\mathrm{Mg}$ at $\mathbf{7 . 7 \%}$ ) in comparison with conventional cropping but increased \\ the ascorbic acid by $23.3 \%$, antioxidant activity by $30.3 \%$, and some micro minerals ( $\mathrm{Na}$ at $39.1, \mathrm{Cu}$ at \\ 5.0, Fe at $17.9, \mathrm{Mn}$ at 3.4, and $\mathrm{Zn}$ at $2.1 \%$ ). The organic system can also result in better economic \\ feasibility under assumption that price and expected yield are achieved. The results showed that a \\ decrease in nitrogen supply, which is inherent in organic cropping, enhances the levels of secondary \\ metabolites and micro minerals, which are associated with increased free radical scavengers and \\ antioxidant activity in plant tissue.
}

Key words: Phenol, sugar, organic acid, antioxidant activity, minerals, economic feasibility.

\section{INTRODUCTION}

The red beetroot (Beta vulgaris L. var. vulgaris) is a traditional and popular vegetable in many parts of the world. It is especially rich in fiber as well as in sugars, but has a moderate caloric value. The soluble and cell wall associated phenolics are bioactive compounds (Kugler et al., 2007; Pradhan et al., 2010). In recent years, there has been an increased interest in food quality, composition, and health effects (Reganold et al., 2010). Many research groups have studied nutritional and quality parameters in fruits and vegetables produced using different production systems, but conclusive evidence supporting the nutritional or qualitative superiority of either

*Corresponding author. E-mail: sasa.straus@panvita.si. Tel: + 386253036 27. Fax: + 38625303632. production system does not currently exist. Findings point toward the understanding that, in most cases, organically produced foods contain greater amounts of healthpromoting contents and lower amounts of harmful contents (Rembialkowska, 2007).

It is generally assumed that climate, soil types, cultivar, fertilizers, irrigation practices, uses of pesticides and herbicides, maturity at harvest, and postharvest handling are the most important variables that affect the nutrition and quality of fruits and vegetables (Kalt, 2005; NunezDelicado et al. 2005). Studies are not always consistent because they have different approaches to sampling namely: samples from the stores or sampling different crop varieties. Different approaches to sampling can strongly bias the results. A greater number of studies compared mainly cabbage, carrots, tomatoes, and potatoes (Lairon, 2010). Little information is available 
Table 1. Total inputs of nutrients and plant protection application for different treatments according to CON, INT, ORG, and control plots in year 2009 and 2010.

\begin{tabular}{|c|c|c|c|c|c|c|c|}
\hline \multirow[t]{2}{*}{ PS } & \multicolumn{3}{|c|}{ Pesticides applied $\left(\mathrm{L} \mathrm{ha}^{-1}\right)$} & \multirow[t]{2}{*}{$\begin{array}{l}\text { Fertilizers } \\
\text { applied }\end{array}$} & \multicolumn{3}{|c|}{$\begin{array}{l}\text { Amounts of nutrients appliec } \\
\qquad\left(\mathrm{kg} \mathrm{ha}^{-1}\right)\end{array}$} \\
\hline & Herbicides & Fungicides & Insecticides & & $\mathbf{N}$ & $\mathbf{P}$ & $\mathrm{K}$ \\
\hline CON & 5.5 & 0.8 & 0.5 & Mineral & 125 & 70 & 300 \\
\hline INT & 5.5 & 0.8 & 0.5 & Mineral & 130 & 30 & 300 \\
\hline ORG & 0 & 0 & 0 & Manure & 106 & 36 & 162 \\
\hline Control & 0 & 0 & 0 & - & 0 & 0 & 0 \\
\hline
\end{tabular}

${ }^{2}$ Cattle manure was analyzed for their contents of NPK before application.

about the internal quality, mineral content, and composition of the red beetroot. The red beetroot is regarded as a good potential source of antioxidants and phenols (Bavec et al., 2010; Kugler et al., 2007; Kujala et al., 2000; Mattila and Hellström, 2007; Mäder et al., 1993; Pradham et al., 2010; Rodriguez-Sevila et al., 1999).

Farmers are in addition to quality are also interested in economically feasible production. Of particular concern, are the management practices that are cost-effective which give relatively higher returns to farmers' investments (Bamire et al., 2012). The objective of this study was to assess the effect of the different production systems (conventional (CON), integrated (INT), and organic (ORG)) on the composition of nutrients and organic compounds (sugar, organic acid, total phenolic content, the antioxidant activity, and ascorbic acid) and mineral composition in a field trial and also to provide economical assessments of red beet production in different production system.

\section{METHODOLOGY}

\section{Plant material and growing conditions}

The experiment was conducted at the research station in Dolenci, near the Hungarian border (46 ${ }^{\circ} 51^{\prime} 4.43^{\prime \prime} \mathrm{N}, 16^{\circ} 17^{\prime} 15.45^{\prime \prime} \mathrm{E}, 302.1$ m.a.s.l). The annual mean air temperature of the area is $9.7^{\circ} \mathrm{C}$ while the mean minimum monthly temperature is in January at $1.6^{\circ} \mathrm{C}$ and the average maximum monthly temperature is in July at $19.1^{\circ} \mathrm{C}$. Average annual rainfall in the area is $749 \mathrm{~mm}$. The $80 \mathrm{~m}^{2}$ experimental field plot was established in sandy loam (average $\mathrm{pH}$ value $6.3\left[0.1 \mathrm{KCl}\right.$ solution], soil soluble $\mathrm{P}$ at $13 \mathrm{mg} \mathrm{P}_{2} \mathrm{O}_{5} 100 \mathrm{~g} \mathrm{~g}^{-1}$ and soil soluble $\mathrm{K}$ at 34 to $56 \mathrm{mg} \mathrm{K}_{2} \mathrm{O} 100 \mathrm{~g}^{-1}$ at the plowed soil layer). Three production systems and control plots were arranged in a randomized complete block split-plot design with four replications. The production systems differed primarily in plant protection and fertilization strategies. The three systems (CON, INT and ORG) were managed in accordance with $\mathrm{EU}$ and national legislation and rules (Rembialkowska, 2007). In CON, the preventive use of synthetic pesticides is allowed, and in INT, curative use is allowed. In ORG, the use of natural insecticides and fungicides are allowed, but herbicides are not allowed. In CON, mineral fertilizing is the farmers' choice, and in INT, the amount of mineral fertilizers that were used is based on soil analysis and nutrient removal estimates. Also, in ORG, fertilization is based on soil analysis and nutrient removal estimates, but fertilizers are organic. In control plots, no fertilization/plant protection was used. In CON and INT, mineral fertilizers were used (amounts are stated in Table 1), and in ORG, manure were used (amount are stated in Table 1) and in the control, none fertilizers were used. Pesticides applied in CON and INT were Fusilade forte (1.5 $\left.\mathrm{L} \mathrm{ha}^{-1}\right)$, Beet up compact $\left(3 \mathrm{~L} \mathrm{ha}{ }^{-1}\right)$ and Agil ( $\left.1 \mathrm{~L} \mathrm{ha}^{-1}\right)$ as herbicides, Amistar Extra $\left(0.8 \mathrm{~L} \mathrm{ha}^{-1}\right)$ as fungicides and Bulldock $\left(0.5 \mathrm{~L} \mathrm{ha}^{-1}\right)$ as insecticides. In ORG and control, no plant protection means were applied (Table 1). Other growing conditions, including environmental conditions, soil fertility, irrigation management, and preceding cropping history were identical for all treatments in order to allow a valid comparison. They were performed on the same dates and in the same manner as adjacent fields. The same crop variety was used in all production systems under the study (Beta vulgaris L. subsp. Vulgaris var. conditiva ALEF. Rote Kugel), and they were of conventional origin for CON and INT systems and organic origin for ORG and control systems. The variety of Rote Kugel was chosen because of its disease and pest resistance and fresh consumption and processing qualities. The whole experimental plot was managed according to organic farming standards for two years before the trials started.

\section{Plant harvest and morphology parameters}

Samples of red beetroots were picked on August 27th 2009 and in 2010 from the center of the experimental plot and samples were cleaned. Harvesting was performed when more than $90 \%$ of the plants were at technological maturity and their quality parameters (root shape, root size, color, firmness, smoothness, freedom from defects, and intensive and uniform color) corresponded to a marketable class. The roots were considered non-marketable, if one of the visually assessed parameters was scored unacceptable. After the harvest, total beetroot root yield from each plot was determined. The physical attributes including mass, height, diameter of the roots, and the average number and length of leaves of red beetroots were measured in 10 plants from the center of each plot (Table 2). For the analyses, another ten representative red beetroot roots were taken from each plot.

\section{Analysis of individual carbohydrates and organic acids}

The fresh red beetroot samples were analyzed for their content of carbohydrates (sucrose, glucose, and fructose) and organic acids (malic, citric, and fumaric). In the laboratory, samples from each plot were peeled, cut into small pieces, and thoroughly mixed. Of the fresh mass, $5 \mathrm{~g}$ were immersed in $15 \mathrm{ml}$ of double-distilled water and homogenized with T-25 ULTRA-TURRAX (Ika-Labortechnik, Stauden, Germany). The vegetable samples were left for half an hour at room temperature and stirred frequently before extraction. The extracted samples were centrifuged at $15,550 \mathrm{~g}$ for seven min at $10^{\circ} \mathrm{C}$ (Eppendorf Centrifuge 5810R, Hamburg, Germany). The supernatants were filtered through a $0.45 \mu \mathrm{m}$ filter (Macherey- 
Table 2. Yield (Y), dry matter (DM), and physical attribute (mass of root, root length, diameter of root, number of leaves, average leaf length ( $L$ length) of red beetroot in relation to various production systems.

\begin{tabular}{lccccccc}
\hline Parameter & $\mathbf{Y}\left(\mathbf{t ~ h a} \mathbf{~}^{-1}\right)$ & DM $\left(\mathbf{g ~ 1 0 0 ~} \mathbf{g}^{-1}\right)$ & Mass $(\mathbf{g})$ & Length $(\mathbf{c m})$ & Diameter $(\mathbf{c m})$ & No. of leaves & L length $(\mathbf{c m})$ \\
\hline CON & $33^{\mathrm{a}}$ & $14.3^{\mathrm{a}}$ & $385^{\mathrm{a}}$ & $10^{\mathrm{a}}$ & $26^{\mathrm{a}}$ & $14^{\mathrm{a}}$ & $36^{\mathrm{a}}$ \\
INT & $33^{\mathrm{a}}$ & $14.6^{\mathrm{a}}$ & $381^{\mathrm{a}}$ & $10^{\mathrm{a}}$ & $25^{\mathrm{a}}$ & $13^{\mathrm{ab}}$ & $36^{\mathrm{a}}$ \\
ORG & $24^{\mathrm{b}}$ & $15.1^{\mathrm{b}}$ & $322^{\mathrm{a}}$ & $8^{\mathrm{b}}$ & $21^{\mathrm{b}}$ & $12^{\mathrm{b}}$ & $30^{\mathrm{b}}$ \\
Control & $8^{\mathrm{c}}$ & $15.3^{\mathrm{b}}$ & $174^{\mathrm{b}}$ & $8^{\mathrm{b}}$ & $19^{\mathrm{b}}$ & $12^{\mathrm{b}}$ & $27^{\mathrm{b}}$ \\
\hline
\end{tabular}

${ }^{1}$ Any two means within a column not followed by the same letter are significantly different at $P \leq 0.05$ (Duncan's multiple range test).

Nagel, Düren, Germany), transferred to a vial, and analyzed according to the method described by Sturm et al. (2003), using high-performance liquid chromatography (HPLC; Thermo Scientific, Finnigan Spectra System, Waltham, MA, USA). For each analysis, $0.020 \mathrm{ml}$ of the sample was used. An analysis of sugars was carried out using a Rezex-RCM-monosaccharide column $(300 \times 7.8 \mathrm{~mm}$; Phenomenex, Torrance, CA) with column temperature maintained at $65^{\circ} \mathrm{C}$; and an $\mathrm{RI}$ detector with a flow of $0.6 \mathrm{ml} \mathrm{min}^{-1}$. For the mobile phase, double distilled water and an $\mathrm{Rl}$ detector for identification were used. Organic acids were analyzed using a Rezex-ROA-organic acid column $(300 \times 7.8 \mathrm{~mm}$; Phenomenex, Torrance, CA), and the UV detector set at $210 \mathrm{~nm}$ with a flow of 0.6 $\mathrm{ml} \mathrm{min}^{-1}$, maintaining the column temperature at $65^{\circ} \mathrm{C}$. For the mobile phase, $4 \mathrm{mM}$ of sulphuric acid $\left(\mathrm{H}_{2} \mathrm{SO}_{4}\right)$ was used. The concentrations of carbohydrates and organic acids were calculated with the help of corresponding external standards.

\section{Determination of total phenolic content}

In the laboratory, red beetroot samples from each plot were peeled, cut into small pieces, and thoroughly mixed. Of each sample, $5 \mathrm{~g}$ were extracted with methanol $(10 \mathrm{ml})$ and homogenized with the T25 ULTRA-TURRAX. Then, the samples were sonicated with a Sonis 4 (Iskra pio, Ljubljana, Slovenia) for $1 \mathrm{~h}$ in a cooled water bath. After extraction, the sample extracts were centrifuged for 10 $\min$ at $15,550 \mathrm{~g}$ at $4^{\circ} \mathrm{C}$. The supernatant was filtered through a Chromafil AO-45/25 polyamide filter (Macherey-Nagel, Düren, Germany) and transferred to a vial.

The total phenolic content (TPC) of the extracts was assessed using the Folin-Ciocalteu phenol reagent method (Singleton and Rossi, 1965). $6 \mathrm{ml}$ of twice-distilled water and $0.50 \mathrm{ml}$ of the FolinCiocalteu reagent were added to $0.10 \mathrm{ml}$ of the sample extracts, and after waiting for between $8 \mathrm{~s}$ and $8 \mathrm{~min}$ at room temperature, $1.5 \mathrm{ml}$ of sodium carbonate $(20 \% \mathrm{w} / \mathrm{v})$ and $1.9 \mathrm{ml}$ of twice-distilled water were added. The extracts were mixed and allowed to stand for $30 \mathrm{~min}$ at $40^{\circ} \mathrm{C}$ before their absorbencies were measured at 765 $\mathrm{nm}$ on a Lambda Bio 20 UV/VIS spectrophotometer (Perkin-Elmer, Waltham, MA). A mixture of water and reagents were used as blank. The total phenolic content was expressed as Gallic acid equivalents (GAE) in mg per $\mathrm{g} F W$ of red beetroot and absorptions were measured in triplicate.

\section{Determination of antioxidant activity}

The extraction of red beetroot samples for the determination of antioxidant activity was made according to the same protocol described earlier for the assessment of TPC. The free radical scavenging activity of the red beetroot extracts was measured according to the DPPH (1, 1 diphenil-2-picrylhydrazyl) method reported by Brand-Williams et al. (1995), with slight modifications. $0.050 \mathrm{ml}$ of the extract was placed in 96-well microplates, and 0.20 $\mathrm{ml}$ of $0.1 \mathrm{mM}$ methanolic solution of DPPH was added and allowed to react in the dark at room temperature. The decrease in the absorbance of DPPH at $520 \mathrm{~nm}$ was measured at 5 min intervals using a spectrophotometer (Perkin-Elmer, Waltham, MA) until the absorbance stabilized (30 min). Methanol was used as a blank, and DPPH solution without sample was used as a control. All samples were prepared in triplicate. The determination of the antioxidant activity of the samples at various concentrations was made using the Trolox standard curve. The DPPH radical scavenging activity of red beetroot extracts was expressed as $\mu \mathrm{M}$ Trolox equivalents (TE) per g FW of red beetroot.

\section{Analysis of mineral elements}

Sub-samples of red beetroot were finely cut and dried at $60^{\circ} \mathrm{C}$. Dry sample were ground and then burned to ashes in a muffle furnace at $550 \pm 15^{\circ} \mathrm{C}$. Ash was dissolved in hydrochloric acid, and the insoluble part was removed using filtration. In the filtrate, calcium $(\mathrm{Ca})$, magnesium $(\mathrm{Mg})$, potassium $(\mathrm{K})$, sodium $(\mathrm{Na})$, copper $(\mathrm{Cu})$, manganese $(\mathrm{Mn})$, iron $(\mathrm{Fe})$, and zinc $(\mathrm{Zn})$ were identified using atomic absorption spectrometry (atomic absorption spectrometry AAnalyst 800 , Perkin Elmer), and the content of phosphorus $(P)$ was determined spectrophotometrically using the vanadatic method at $435 \mathrm{~nm}$ (UV/VIS spectrophotometer Cary 100, Varian). According to ISO 6869 (2000), determination of the contents of calcium (Ca), copper $(\mathrm{Cu})$, iron $(\mathrm{Fe})$, magnesium $(\mathrm{Mg})$, manganese $(\mathrm{Mn})$, potassium $(\mathrm{K})$, sodium $(\mathrm{Na})$ and zinc $(\mathrm{Zn})$ was performed. Using the atomic absorption spectrometry method by ISO 6491 (1998), the determination of phosphorus content was performed by spectrometric method.

\section{Determination of ascorbic acid}

For the determination of ascorbic acid, samples of red beetroot were finely cut and homogenized. Ascorbic acid was extracted from samples with Met-Phosphoric acid. Then, the reduction of dehydro $L(+)$ ascorbic acid in the $L(+)$ ascorbic acid was conducted by adding $L$-cysteine. The $L(+)$ ascorbic acid in the solution was determined using high performance liquid chromatography (HP 1100, Hewlet Packard) with a UV detector at a wavelength of 265 $\mathrm{nm}$. The method was performed according to SIST EN 14130:2003 and determination of vitamin C using HPLC.

\section{Feasibility analysis}

If we also take into account the ratio between total revenue and total costs for the production of cabbage and red beets in particular production systems, we get a picture of production system economic feasibility. We used a feasibility analysis based on model enterprise budgets. The data are derived from field trials. The price used is the average prices in the wholesale buying (Statistical office, 2012). Retail prices can be higher. For organic production 
Table 3. Concentration of sugars, ascorbic acid, and total phenolic compounds (TPC) of red beetroot in relation to various production systems.

\begin{tabular}{lccccc}
\hline Parameter & Glucose $\left(\mathbf{g ~ k g}^{-1}\right)$ & Fructose $\left(\mathbf{g ~ k g}^{-1}\right)$ & Sucrose $\left(\mathbf{g ~ k g}^{-1}\right)$ & Ascorbic acid $\left(\mathbf{m g ~} \mathbf{~ 1 0 0 ~} \mathbf{~ g}^{-1}\right)$ & TPC $\left(\mathbf{m g ~ G A E ~ g}^{-1} \mathbf{F W}\right)$ \\
\hline CON & $0.2^{\mathrm{a}}$ & $1.0^{\mathrm{a}}$ & $24.8^{\mathrm{a}}$ & $23.3^{\mathrm{a}}$ & $0.67^{\mathrm{a}}$ \\
INT & $0.3^{\mathrm{a}}$ & $0.9^{\mathrm{a}}$ & $35.5^{\mathrm{a}}$ & $23.4^{\mathrm{a}}$ & $0.77^{\mathrm{a}}$ \\
ORG & $0.3^{\mathrm{a}}$ & $1.1^{\mathrm{a}}$ & $27.6^{\mathrm{a}}$ & $34.3^{\mathrm{b}}$ & $0.78^{\mathrm{a}}$ \\
Control & $0.1^{\mathrm{a}}$ & $1.0^{\mathrm{a}}$ & $30.1^{\mathrm{a}}$ & $33.9^{\mathrm{b}}$ & $0.80^{\mathrm{a}}$ \\
\hline
\end{tabular}

${ }^{1}$ Any two means within a column not followed by the same letter are significantly different at $P \leq 0.05$ (Duncan's multiple range test).

system, four scenarios were presented with different prices of the product. The price in scenario 1 was equal to the price in other systems. The price in scenario 2 is for $20 \%$ higher, in scenario 3 for $50 \%$ higher and in scenario 4 for $100 \%$ higher. The prices in the scenarios represent a typical price for a relationship between ORG and CON and the index for red beet is 234 (Kuhar and Juvancic, 2010).

\section{Statistical design and methods}

An analysis of variance was performed to evaluate the differences in measured parameters, with production systems as a factor, using a Statgraphics Centurion (Version XV, StatPoint Technologies, Inc., Warranton, VA). Thereafter, parameters were compared using Duncan's multiple range tests $(P \leq 0.05)$. To examine the correlations between TPC and antioxidant activities, a correlation analysis (Pearson's correlation coefficient) was performed.

\section{RESULTS AND DISCUSSION}

\section{Yield and quality parameters}

The marketable yield (red beetroot roots) was significantly higher in CON and INT, than in ORG $(27 \%$ lower) and control plots (75\% lower) (Table 2). The yield between CON and INT were not significantly different. The physical appearance of the red beetroots was significantly different between INT and CON on the one side, and ORG and Control on the other side. The average root from ORG weighted $322 \mathrm{~g}$ (in CON $385 \mathrm{~g}$ ), the diameter was $5 \mathrm{~cm}$ smaller (in ORG $26 \mathrm{~cm}$ and in CON $21 \mathrm{~cm}$ ), and length is $2 \mathrm{~cm}$ shorter (in ORG $8 \mathrm{~cm}$ and in CON $10 \mathrm{~cm}$ ) than in CON. This corresponds with the growth/differentiation balance theory (Lorio, 1986; Herms and Mattson, 1992), which states that a plant in any given situation will assess the resources available to it and optimize its investment in the process of growth or differentiation.

\section{Sugars}

The concentrations of individual sugars were assessed. The most abundant sugar in red beetroot was found to be sucrose whereas fructose and glucose were found only in small amounts (Table 3). This corresponds with the findings of other research (Bavec et al., 2010; RodriguezSevilla et al., 1999). The total sugar content ranged from $26.0 \mathrm{mg} \mathrm{g}^{-1}$ in CON to $36.9 \mathrm{mg} \mathrm{g}^{-1}$ in ORG, but the differences were not significant.

\section{Ascorbic acid}

The ascorbic acid contents were significantly higher in ORG (34.3 mg $100 \mathrm{~g}^{-1}$ ) and Control (33.9 mg $100 \mathrm{~g}^{-1}$ ) than in INT (23.4 mg $\left.100 \mathrm{~g}^{-1}\right)$ and CON (23.3 mg $\left.100 \mathrm{~g}^{-1}\right)$ (Table 3). The vitamin C content of red beetroot is twice as high as the one of other root vegetables (Nutrition data, 2011). The ascorbic acid content has been found to decrease in several fruits and vegetables when $\mathrm{N}$ fertilization is increased (Bijelic et al., 2011; Lairon, 2010).

\section{Total phenolic content and antioxidant activity}

The total phenolic content (TPC) of red beetroot samples ranged from 0.67 to $0.80 \mathrm{mg} \mathrm{g}^{-1} \mathrm{FW}$ GAE (Table 3). The values were higher than those in previously published data. Kujala et al. (2000) estimated total phenolic content at $4.2 \mathrm{mg} \mathrm{g}^{-1}$ in flesh (dry weight). Our values regarding the dry matter (DM) content were between $4.15 \mathrm{mg} \mathrm{g}^{-1}$ DM GAE and $4.96 \mathrm{mg} \mathrm{g}^{-1} \mathrm{DM}$ GAE. The results were similar to the findings of Kujala et al. (2000). Nevertheless, a trend of more total phenolic content in ORG and in control plots was observed. This corresponds with the literature review by Rembialkowska (2007). Total phenolic content and antioxidant activity, which is partly attributed to betacyanins, tend to increase when the $\mathrm{N}$ supply is restricted (ORG) (Close and McArthur, 2002; Sanchez et al., 2000; Salahas et al., 2011). This could be confirmed from the results of the unfertilized control and the ORG and the system with the smallest nutrient input systems (Table 1). Limited fertilization means higher stress for plants. Phenols play a role in plant defense mechanisms (Mikulic et al., 2007).

The statistical analysis of the relationship between total phenolic content and antioxidant activity of vegetables showed a positive and middle significant relationship $\left(r^{2}=0.6578, P \leq 0.05\right)$. The results indicate that vegetables containing high phenolics may be a good source of 


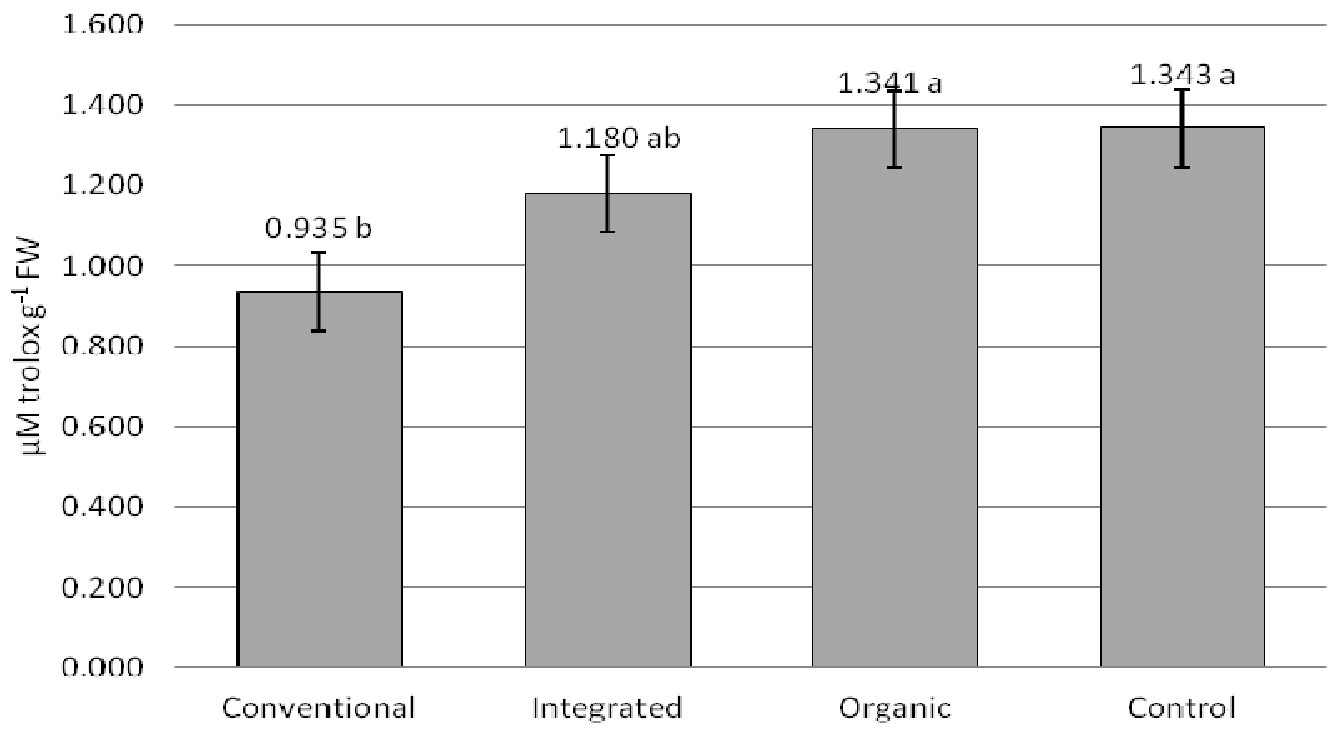

Figure 1. Antioxidant activity of red beetroot depending on the farming system expressed as $\mu \mathrm{M}$ Trolox equivalents per g FW of red beetroot. Average values are depicted. The different letters $(a-b)$ above the bars mean significant differences in antioxidant activity between the production systems at $P \leq 0.05$ (Duncan test).

Table 4. Concentrations of organic acids (citric, fumaric, malic, and shikimic) and total organic acids in roots of red beetroot in relation to various production systems.

\begin{tabular}{lccccc}
\hline Parameter & Citric $\left(\mathbf{m g ~ k g}^{-1} \mathbf{~ F W}\right)$ & Fumaric $\left(\mathbf{m g ~ k g}^{-1} \mathbf{F W}\right)$ & Malic $\left(\mathbf{g ~ k g}^{-1} \mathbf{F W}\right)$ & Shikimic $\left.\mathbf{~ g ~ k g ~}^{-1} \mathbf{~ F W}\right)$ & Total $\left(\mathbf{g ~ k g}^{-1} \mathbf{~ F W}\right)$ \\
\hline CON & $301.6^{\mathrm{a} 1}$ & $0.4^{\mathrm{a}}$ & $1.6^{\mathrm{a}}$ & $31.9^{\mathrm{a}}$ & $33.8^{\mathrm{a}}$ \\
INT & $351.5^{\mathrm{a}}$ & $0.7^{\mathrm{ab}}$ & $2.4^{\mathrm{a}}$ & $21.3^{\mathrm{a}}$ & $24.0^{\mathrm{a}}$ \\
ORG & $369.2^{\mathrm{a}}$ & $0.1^{\mathrm{b}}$ & $1.9^{\mathrm{a}}$ & $32.1^{\mathrm{a}}$ & $34.3^{\mathrm{a}}$ \\
Control & $274.2^{\mathrm{a}}$ & $0.5^{\mathrm{a}}$ & $1.6^{\mathrm{a}}$ & $31.6^{\mathrm{a}}$ & $33.5^{\mathrm{a}}$ \\
\hline
\end{tabular}

${ }^{1}$ Any two means within a column not followed by the same letter are significantly different at $P \leq 0.05$ (Duncan's multiple range test).

antioxidants (Kaur and Kappor, 2002; Flores et al., 2009). Antioxidant activity, expressed as Trolox equivalents (TE), ranged from $0.94 \mu \mathrm{M} \mathrm{TE} \mathrm{g}{ }^{-1} \mathrm{FW}$ in CON samples to $1.34 \mu \mathrm{M} \mathrm{TE} \mathrm{g}^{-1} \mathrm{FW}$ in control samples of red beetroots, (Figure 1). Significant differences were detected between the CON and INT production systems on the one side and ORG and control systems on the other side. Kugler et al. (2007) reported much higher values TE $(11.103 \mu \mathrm{M}$ TE $g^{-1} \mathrm{DM}$ ) for red beetroot samples from red beetroot roots of the same variety. The differences could be attributed to the different presentation of the results. We presented the fresh red beetroot, and in mentioned studies, the dry matter was presented. If the DM content in the final results is included, values lie in a similar range (6.19 $\mu \mathrm{M} \mathrm{TE} \mathrm{g}^{-1}$ DM to $\left.4.63 \mu \mathrm{M} \mathrm{TE} \mathrm{g}^{-1} \mathrm{DM}\right)$.

\section{Organic acids}

Four organic acids were identified in the red beetroot: Citric, malic, shikimic, and fumaric acids (Table 4). The most abundant was shikimic acid. Significant differences were found for fumaric acid content between CON, control on the one side and ORG on the other side. The differences of total amount of organic acid between the production systems were not significant. In other studies, the highest content of organic acid was found in ORG production systems (Sousa et al., 2006; Wang et al., 2008; Röhling and Engel, 2010). The reasons for a higher acid content in some samples could be linked to lower nutrient availability, especially in the control system (Lerdau and Coley, 2002). The different fertilizer regimes used in different production systems have an effect on organic acids and other parameters of internal quality.

\section{Mineral composition}

Red beetroots from ORG and the control systems had a tendency to accumulate significantly higher amounts of dry matter content in red beetroot roots than in CON and INT (Table 2). The macro and micro minerals including $P$, 
Table 5. Effect of production system (PS) and year (Y) on mineral composition of red beetroot.

\begin{tabular}{|c|c|c|c|c|c|c|c|c|c|c|c|}
\hline Factor & $\mathbf{N}$ & $\mathbf{P}$ & $\mathrm{K}$ & $\mathrm{Ca}$ & $\mathrm{Mg}$ & $\mathrm{Na}$ & $\mathrm{Cu}$ & $\mathrm{Fe}$ & Mn & $\mathrm{Zn}$ & $\mathrm{pH}$ \\
\hline PS & \multicolumn{6}{|c|}{$\mathrm{g} \mathrm{kg}^{-1}$ in DM } & \multicolumn{5}{|c|}{$\mathrm{mg} \mathrm{kg}^{-1}$ in DM } \\
\hline $\mathrm{CON}$ & $18.3^{\mathrm{a} 1}$ & $2.6^{\mathrm{a}}$ & $36.6^{\mathrm{a}}$ & $1.5^{\mathrm{a}}$ & $2.3^{\mathrm{a}}$ & $2.3^{\mathrm{a}}$ & $10.0^{\mathrm{a}}$ & $192.5^{\mathrm{a}}$ & $94.4^{c}$ & $56.3^{b}$ & $6.2^{b}$ \\
\hline INT & $18.5^{\mathrm{a}}$ & $2.3^{\mathrm{a}}$ & $32.9^{\mathrm{a}}$ & $1.4^{\mathrm{b}}$ & $1.9^{\mathrm{a}}$ & $2.3^{\mathrm{a}}$ & $9.3^{b}$ & $189.1^{\mathrm{a}}$ & $94.4^{\mathrm{C}}$ & $57.4^{\mathrm{b}}$ & $6.1^{\mathrm{a}}$ \\
\hline ORG & $14.5^{\mathrm{a}}$ & $2.0^{\mathrm{b}}$ & $31.8^{\mathrm{b}}$ & $1.5^{\mathrm{a}}$ & $2.1^{\mathrm{a}}$ & $3.2^{b}$ & $10.5^{a}$ & $234.4^{\mathrm{b}}$ & $97.7^{\mathrm{b}}$ & $57.5^{\mathrm{b}}$ & $6.2^{b}$ \\
\hline Control & $14.2^{\mathrm{a}}$ & $2.2^{\mathrm{a}}$ & $28.6^{\mathrm{b}}$ & $1.4^{\mathrm{b}}$ & $2.0^{\mathrm{a}}$ & $1.8^{\mathrm{a}}$ & $8.4^{\mathrm{b}}$ & $252.5^{\mathrm{b}}$ & $133.5^{\mathrm{a}}$ & $63.5^{\mathrm{a}}$ & $6.2^{b}$ \\
\hline \multicolumn{12}{|l|}{ Year } \\
\hline 2009 & $15.9^{\mathrm{a}}$ & $2.1^{\mathrm{b}}$ & $26.7^{\mathrm{b}}$ & $1.2^{\mathrm{b}}$ & $1.4^{\mathrm{a}}$ & $2.3^{\mathrm{a}}$ & $8.0^{\mathrm{a}}$ & $200.7^{b}$ & $86.7^{b}$ & $51.7^{\mathrm{b}}$ & $6.0^{\mathrm{b}}$ \\
\hline 2010 & $16.7^{\mathrm{a}}$ & $2.5^{\mathrm{a}}$ & $38.2^{\mathrm{a}}$ & $1.7^{\mathrm{a}}$ & $2.7^{b}$ & $2.6^{\mathrm{a}}$ & $11.0^{\mathrm{a}}$ & $233.6^{a}$ & $123.4^{\mathrm{a}}$ & $65.7^{\mathrm{a}}$ & $6.4^{\mathrm{a}}$ \\
\hline Average & 16.3 & 2.3 & 32.5 & 1.5 & 2.1 & 2.4 & 9.5 & 217.1 & 105.0 & 58.7 & 6.2 \\
\hline
\end{tabular}

${ }^{1}$ Any two means within a column not followed by the same letter are significantly different at $P \leq 0.05$ (Duncan's multiple range test).

$\mathrm{K}, \mathrm{Ca}, \mathrm{Na}, \mathrm{Cu}, \mathrm{Fe}, \mathrm{Mn}$, and $\mathrm{Zn}$, were significantly affected by the production systems (PS) (Table 5). The CON and INT showed significantly higher amount of $\mathrm{K}$ in comparison with ORG and Control. The amount of $\mathrm{Na}$ is significantly higher in ORG. The ORG and control showed significantly higher concentrations of $\mathrm{Fe}$. The control showed significantly higher concentration of $\mathrm{Mn}$ and $\mathrm{Zn}$ concentrations.

Previous plant nutrition research has demonstrated that the lower yield of ORG arises from deficiencies in $\mathrm{N}$ (Haneklaus et al., 2002). This is attributed to the fact that, although, organic manure usually contains the necessary amount of $\mathrm{N}$, only part of this nutrient is immediately available to plants (Banuelos and Pasakdee, 2002). In our study, the decrease in $\mathrm{N}$ observed in red beetroot in the order CON/INT/ORG/CONTROL was correlated with a decrease in total fruit yields, as mentioned by other studies (Rembialkowska, 2007). The higher N, P, and K concentration observed in CON and INT systems, compared to ORG, could be attributed to increasing $\mathrm{K}$ uptake by plants in CON and INT systems as a result of the synthetic $\mathrm{K}$ fertilization supply. $\mathrm{K}$ uptake is also improved by higher $\mathrm{N}$ uptake.

According to the present study, the type of fertilization was a main factor in modifying the nutritional quality of red beetroots. Having compared the influence of organic manure and synthetic mineral fertilization on the plant nutritional value, it was indicated that the organic fertilization contributed to a considerable improvement in the chemical composition of vegetables with respect to the occurrence of microelements, vitamins, and phenolic compounds. When the availability of nitrogen is limited, the secondary metabolites are intensively synthesized and act as an immune system for the plants (Lairon, 2010).

\section{Feasibility analysis}

The data for feasibility analysis are obtained in the field trials, where agronomic treatment can be optimal. Table 6 presents financial results (net return) for all three systems and control. We used sensitivity analysis (4 scenarios) in order to show the influence of different prices on the feasibility of ORG. The feasibility analysis showed that production can be the most economically feasible when using the ORG (1.1), when higher selling prices are achieved. Production is the least economically feasible in the control (0.5), mainly due to low yields. The differences in financial results were significantly different for all production system.

The production of red beet is economically feasible only in scenario 4 , where the prices were twice of the other production systems. Negative net return for red beet increased without subsidies.

\section{CONCLUSION AND RECOMMENDATION}

The experiment showed that there were significant differences in the quality of red beets from different production systems. We can confirm that ORG red beets were characterized by significantly higher antioxidant activity and higher contents of ascorbic acid and some micro minerals compared with CON or INT red beet production. The highest difference between the production systems was the result of the use of artificial fertilizers and synthetic pesticides in CON and INT, which were not permitted in ORG. The theories of differences in $\mathrm{N}$ uptake and the reduction of secondary metabolites can be confirmed using this study.

The economic feasibility analysis showed that the production is feasible only in ORG when selling price is twice as high as in other production systems. Because of the higher quality, and thus, a favorable impact on health, future research should consider how to increase the yield and physical attributes of the crops without losing quality, and it should study how to effectively fight against pests and diseases. This would definitely increase organically management field. 
Table 6. Financial analysis for red beet from different production systems.

\begin{tabular}{clcccc}
\hline Price (\%) & Red beet & $\begin{array}{c}\text { Total revenue } \\
(\text { TR) }(\boldsymbol{\epsilon})\end{array}$ & $\begin{array}{c}\text { Total costs } \\
(\text { TC) }(\boldsymbol{\epsilon})\end{array}$ & $\begin{array}{c}\text { Financial result } \\
(\text { FR) }(\boldsymbol{\epsilon})\end{array}$ & $\begin{array}{c}\text { Financial result without } \\
\text { subsidies }(\boldsymbol{\epsilon})^{1}\end{array}$ \\
\hline 100 & CON & $2,787.90^{\mathrm{a}}$ & $4,269.43^{\mathrm{a}}$ & $-1,481.53^{\mathrm{a}}$ & $-1,481.53^{\mathrm{a}}$ \\
100 & INT & $2,986.70^{\mathrm{b}}$ & $4,198.69^{\mathrm{b}}$ & $-1,211.99^{\mathrm{b}}$ & $-1,543.99^{\mathrm{b}}$ \\
& ORG & & & & \\
100 & Scenario 1 & $2,425.50^{\mathrm{c}}$ & $3,893.85^{\mathrm{c}}$ & $-1,468.35^{\mathrm{c}}$ & $-2,098.35^{\mathrm{c}}$ \\
120 & Scenario 2 & $2,784.60^{\mathrm{d}}$ & $3,893.85^{\mathrm{c}}$ & $-1,109.25^{\mathrm{d}}$ & $-1,739.25^{\mathrm{d}}$ \\
150 & Scenario 3 & $3,323.25^{\mathrm{e}}$ & $3,893.85^{\mathrm{c}}$ & $-570.60^{\mathrm{e}}$ & $-1,200.60^{\mathrm{e}}$ \\
200 & Scenario 4 & $4,221.00^{\mathrm{f}}$ & $3,893.85^{\mathrm{c}}$ & $327.15^{\mathrm{f}}$ & $195.00^{\mathrm{f}}$ \\
100 & Control & $1,455.00^{\mathrm{g}}$ & $3,226.59^{\mathrm{d}}$ & $-1,771.59^{\mathrm{g}}$ & $-2,401.59^{\mathrm{g}}$ \\
\hline
\end{tabular}

Different letters $(a-g)$ in column mean significant differences between the production system at $p<0.01$ (Duncan's multiple range test). ${ }^{1}$ The last column shows net return without subsidies ( $0 € /$ ha for CON, $332 € /$ ha for INT, $630 € /$ ha for ORG and control).

\section{ACKNOWLEDGEMENT}

The results presented in this paper are the output of a research project (P-MR-14/09), which is partly financed by the European Social Fund of the European Union.

\section{REFERENCES}

Bamire AS, Abaidoo R, Jemo M, Abdoulaye T, Yusuf A, Nwoke OC (2012). Profitability analysis of commercial chemical and biological crop products among farm households in agro-ecological zones of West Africa. Afr. J. Agric. Res. 7:3385-3394.

Banuelos GS, Pasakdee D (2002). Effect of organic fertilizers on vegetable production. Biocycle 43:63-64.

Bavec M, Turinek M, Grobelnik Mlakar S, Slatnar A, Bavec F (2010). Influence of industrial and alternative farming systems on contents of sugar, organic acids, total phenolic content, and the antioxidant activity of Red Beet (Beta vulgaris L. ssp. vulgaris Rote Kugel). J. Agric. Food Chem. 58:825-831.

Bijelic SM, Golosin BR, Todorovic JIN, Cerovic JB, Popovic BM (2011). Genotypes from physicochemical fruit characteristics of Cornelian Cherry (Cornus mas L.) genotypes from Serbia. Hortsci. 46:849-853.

Brand-Williams W, Cuvelier ME, Berset C (1995). Use of a free radical method to evaluate antioxidant activity. Lebensm.-Wiss.+Technol. 28:25-30.

Close DC, McArthur C (2002). Rethinking the role of many plant phenolics - protection from photo damage not herbivores? Oikos, 99:166-172.

Flores P, Hellin P, Fenoll J (2009). Effect of manure and mineral fertilization on pepper nutritional quality. J. Sci. Food Agric. 89:15811586.

Haneklaus S, Hagel I, Paulsen H, Schnug E (2002). Objectives of plant nutrition research in organic farming. Landbauforsch. Völkenrode. 52:61-68.

Herms DA, Mattson WJ (1992). The dilemma of plants: to grow or defend. Q. Rev. Biol. 67:283-335.

International Organization for Standardization, ISO 6869 (2000). Animal feeding stuffs- Determination of the contents of calcium, copper, iron, magnesium, manganese, potassium, sodium and zinc -- Method using atomic absorption spectrometry. ISO Geneva, Switzerland.

International Organization for Standardization, ISO 6491 (1998). Animal feeding stuffs- Determination of phosphorus content - Spectrometric method: ISO Geneva, Switzerland.

Kalt W (2005). Effects of production and processing factors on major fruit and vegetable antioxidants. J. Food Sci. 70:R11-R19.

Kaur C, Kappor HC (2002). Anti-oxidant activity and total phenolic content of some Asian vegetable. Int. J. Food Sci. Technol. 37:153161.
Kugler F, Stintzing F, Carle R (2007). Evaluation of the antioxidant capacity of betalainic fruits and vegetables. J. Appl. Bot. Food Qual. 81:69-76.

Kuhar A, Juvančič $L$ (2010). Determinants of purchasing behavior for organic and integrated fruits and vegetables in Slovenia. Agric. Econ. Rev. 11:70-83.

Kujala TS, Loponen JM, Klika KD, Pihlaja K (2000). Phenolics and betacyanins in red beetroot (Beta vulgaris) root: distribution and effect of cold storage on the content of total phenolisc and three individual compounds. J. Agric. Food Chem. 48:5338-5342.

Lairon D (2010). Nutritional quality and safety of organic food. A review. Agron. Sustain. Dev. 30:1-9.

Lerdau M, Coley PD (2002). Benefits of the carbon-nutrient balance hypothesis. Oikos, 98:534-536.

Lorio PL (1986). Growth-differentiation balance: A basis for understanding southern pine beetle-tree interactions. For. Ecol. Man. 14:259-273.

Mäder P, Pfiffner L, Niggli U, Velimirov A, Boltzmann L, Balzer U, Balzer F, Besson J (1993). Effect of three farming systems (Bio-dynammic, bio-organic, conventional) on yield and quality of beetroot (Beta vulgaris $L$. var. esculenta $L$.) in a seven year crop rotation. Acta Hortic. 339:11-39.

Mattila P, Hellström J (2007). Phenolic acids in potatoes, vegetables, and some of their products. J. Food Compos. Anal. 20:152-160.

Mikulic Petkovsek M, Stampar F, Veberic R (2007). Parameters of inner quality of the apple scab resistant and susceptible apple cultivars (Malus domestica Borkh.). Sci. Hortic. 114:37-44.

Nunez-Delicado E, Sanchez-Ferrer A, Garcia-Carmona FF, Lopez Nicolas JM (2005). Effect of organic farming practices on the level of latent ployphenol oxidase in grapes. J. Food Sci. 70:C74-C78.

Nutrition data (2011). <http://www.nutritiondata.com>.

Pradhan SK, Holopainen JK, Weisell J, Heinonen-Tanski H (2010). Human urine and wood ash as plant nutrient for red beet (Beta vulgaris) cultivation: impacts on yield quality. J. Agric. Food Chem. 58:2034-2039.

Reganold JP, Andrews PK, Reeve JR, Carpenter Boggs L, Schadt CW, Alldredge JR, Ross CF, Davies NN, Zhou J (2010). Fruit and soil quality of organic and conventional strawberry agroecosystems. PLoS ONE pp. 5-12346.

Rembialkowska E (2007). Quality of plant products from organic agriculture. J. Sci. Food Agric. 87:2757-2762.

Rodriguez Sevilla M, Villanueva Suarez MJ, Redondo Cuenca A (1999). Effect of processing condition on soluble sugars content of carrot, beetroot and turnip. Food Chem. 66:81-85.

Röhling RM, Engel K (2010). Influence of the input system (conventional versus organic farming) on metabolite profiles of maize (Zea mays) kernels. J. Agric. Food Chem. 58:3022-3030.

Sanchez E, Soto JM, Garcia PC, Lopez Lefebre LR, Rivero RM, Ruiz JM, Romero L (2000). Phenolic and oxidative metabolism as bioindicators of nitrogen deficiency in French bean plants (Phaseolus vulgaris L. cv. strike). Plant Biol. 2:272-277. 
Salahas G, Papasavvas A, Giannakopoulos A, Tselios T, Konstantopoulou H, Savvas D (2011). Impact of nitrogen deficiency on biomass production, leaf gas exchange, and total phenol and betacyanin concentrations in red beet (Beta vulgaris L. ssp. vulgaris) plants. Eur. J. Hort. Sci. 76:194-200.

Singleton VL, Rossi JA (1965). Colorimetry of total phenolics with Phosphomolybdic- Phosphotungstic Acid Reagents. Am. J. Enol. Vitic. 16:144-158.

Sousa C, Pereira MC, Taveira M, Dopico-Garcia S, Valentão P, Pereira AJ, Bento A, Andrade PB (2006). Brassica oleracea var. costata: comparative study on organic acids and biomass production with other cabbage varieties. J. Sci. Food Agric. 89:1083-1089.

Statistical office of Republic Slovenia (2012). Purchase of some important agricultural products, Slovenia, annually, 2010. http://pxweb.stat.si/pxweb/Dialog/varval.asp?ma=1505001E\&ti=\&pat $\mathrm{h}=$. ./Database/Environment/15_agriculture_fishing/02_aricultural_pric e/03_15050_purchase/\&lang $=1$
Sturm K, Koron D, Stampar F (2003). The composition of fruit of different strawberry varieties depending on maturity stage. Food Chem. 83:417-422.

Wang SY, Chen C, Sciarappa W, Wang CY, Camp MJ (2008). Fruit quality, antioxidant capacity and flavonoid content of organically and conventionally grown blueberries. J. Agric. Food Chem. 56:57885794. 